Article

\title{
Above-Ground Biomass and Biomass Components Estimation Using LiDAR Data in a Coniferous Forest
}

\section{Qisheng He ${ }^{1, *}$, Erxue Chen ${ }^{2}$, Ru An ${ }^{1}$ and Yong Li ${ }^{1}$}

1 School of Earth Sciences and Engineering, Hohai University, 1 Xikang Road, Nanjing, Jiangsu 210098, China; E-Mails: anrunj@hhu.edu.cn (R.A.); liyong@hhu.edu.cn (Y.L.)

2 The Research Institute of Forest Resources Information Technique, Chinese Academy of Forestry, Beijing 100091, China; E-Mail: chenerx@caf.ac.cn

* Author to whom correspondence should be addressed; E-Mail: heqis@hhu.edu.cn; Tel./Fax: +86-25-8378-7234.

Received: 8 August 2013; in revised form: 28 October 2013 / Accepted: 15 November 2013 / Published: 20 November 2013

\begin{abstract}
This study aims to estimate forest above-ground biomass and biomass components in a stand of Picea crassifolia (a coniferous tree) located on Qilian Mountain, western China via low density small-footprint airborne LiDAR data. LiDAR points were first classified into ground points and vegetation points. After, vegetation statistics, including height quantiles, mean height, and fractional cover were calculated. Stepwise multiple regression models were used to develop equations that relate the vegetation statistics from field inventory data with field-based estimates of biomass for each sample plot. The results showed that stem, branch, and above-ground biomass may be estimated with relatively higher accuracies; estimates have adjusted $R^{2}$ values of $0.748,0.749$, and 0.727, respectively, root mean squared error (RMSE) values of 9.876, 1.520, and $15.237 \mathrm{Mg} \cdot \mathrm{ha}^{-1}$, respectively, and relative RMSE values of $12.783 \%, 12.423 \%$, and $14.163 \%$, respectively. Moreover, fruit and crown biomass may be estimated with relatively high accuracies; estimates have adjusted $R^{2}$ values of 0.578 and 0.648 , respectively, RMSE

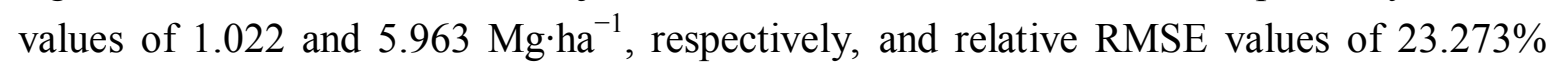
and $19.665 \%$, respectively. In contrast, foliage biomass estimates have relatively low accuracies; they had an adjusted $R^{2}$ value of 0.356 , an RMSE of $3.691 \mathrm{Mg} \cdot \mathrm{ha}^{-1}$, and a relative RMSE of $26.953 \%$. Finally, above-ground biomass and biomass component spatial maps were established using stepwise multiple regression equations. These maps are very useful for updating and modifying forest base maps and registries.
\end{abstract}


Keywords: above-ground biomass; biomass components; LiDAR; coniferous forest; Qilian Mountain

\section{Introduction}

Forest biomass is an essential factor in environmental and climate modeling. Also, standing forest biomass is an essential, active participant in the global carbon cycle. Quantifying the amount of biomass within a forest stand is necessary for property managers to make informed decisions about the value and use of their forested land. Light Detection and Ranging (LiDAR) is one of the most promising remote sensing technologies for estimating various biophysical properties of forests. LiDAR provides the most accurate measurements of terrain elevation and vegetation height; this accuracy holds even on sloped terrain or in dense forests. LiDAR data are well suited to biomass estimation, as point clouds generated from forest canopies can accurately depict the physical characteristics of the canopy surface [1]. These physical characteristics, including tree height, crown diameter, and crown shape correlate with biomass, and may be regressed against either diameter at breast height (DBH) or biomass to obtain general LiDAR-biomass models [2-10]. In comparative studies, LiDAR has produced more accurate estimates of forest biomass than optical satellite sensors [11] and synthetic aperture radar sensors [12-15] have. In addition, biomass values have been estimated without saturation problems, while other remote sensing techniques tend to display asymptotic tendencies at biomass values above a certain threshold [16,17]. Thus, airborne LiDAR holds potential as a valuable data source for generating tree biomass component estimations that comply with international convention requirements regarding carbon stored in trees.

Though above-ground biomass estimates can be extracted from LiDAR data with high accuracies, little was known about biomass component estimates. Forest biomass can be sub-divided into its components, such as stem, branch, and foliage (i.e., the crown and stem); these subdivisions provide additional information for ecosystem management. Typically for timber sales, merchantable stem biomass/volume is of importance, with relationships between stem and non-stem biomass components enabling estimation [18]. Further estimates of biomass components, such as crown biomass, can aid in fuel load assessments and fire management strategies. Canopy fuel characteristics are the most important variables for predicting fire hazard and behavior, thus making predictions of canopy biomass important for many wildfire models [19]. In [20], biomass components, including stem, biomass, and crown biomass were estimated. For LiDAR data, height metrics, such as mean first return height and the percentiles (i.e., the 10th and 90th) of first returns, correlated best with total above-ground and stem biomass. The percentage of first returns above $2 \mathrm{~m}$, and the percentiles (i.e., the 75th and 90th) of first returns height metrics correlated best with crown biomass. A comparison between above-ground components and total biomass indicate that stem biomass displayed the strongest correlation with LiDAR measurements, while crown biomass showed the weakest relationship; the relative root mean squared error (RMSE) ranged from $16 \%$ to $22 \%$, respectively.

In this paper, above-ground biomass and biomass components, including stem, branch, foliage, fruit, and crown biomass were estimated in a stand of Picea crassifolia (a coniferous tree species) on 
Qilian Mountain, western China using low density small-footprint airborne LiDAR data. In the same area, previous studies only focussed on the above-ground biomass [21,22], none covered the biomass components, the biomass distribution and its ecology. The objective of this paper was to investigate the relationship between forest biomass and its components with small-footprint discrete return LiDAR data.

\section{Materials and Methods}

\subsection{Study Area}

The study site of Dayekou is situated in the Qilian Mountain area, with its geographic coordinates ranging from $\mathrm{N} 38^{\circ} 29^{\prime}$ to $38^{\circ} 35^{\prime}$ in latitude and from $\mathrm{E} 100^{\circ} 12^{\prime}$ to $100^{\circ} 20^{\prime}$ in longitude. The site is situated within Gansu province, western China (Figure 1). The elevation varies from 2500 to $3800 \mathrm{~m}$ above sea level. The area has a temperate, continental mountainous climate. During winter, the atmospheric circulation is controlled by the Mongolian anticyclone, which results in cold and dry conditions, with little precipitation. When the atmospheric circulation is affected by the summer continental cyclone, the diurnal difference in temperature is dramatic. The difference of precipitation between summer and winter is also large, and annual precipitation takes place mainly during the summer. Influenced by the climate and the terrain, the prevalent vegetation types in the study area are mountainous pastures and forests. The dominant vegetation includes evergreens, Picea crassifolia and Sabina przewalski, as well as grassland. Vegetation density varies with terrain, soil, water, and climate factors [23]. In the test site, $95 \%$ of the forests are pure forest stands of evergreen Picea crassifolia. This paper consequently only focuses on this forest/species type. In a Picea crassifolia stand, the ground is almost entirely covered by moss, although there are some small shrubs. There are different successional stages of forest (i.e., young, intermediate, and old regrowth) in this area. Thus, in these stands, the forest biomass composition is very variable.

\subsection{LiDAR Data Acquisition}

LiDAR data were acquired on 23 June 2008 using a Riegl LMS-Q560 laser scanner and the Litemapper 5600 system. The scanner operated at a flight altitude of $800 \mathrm{~m}$, and was configured to acquire data using a narrow scan angle of $<0.5 \mathrm{mrad}$ (with respect to either side of the NADIR) and with a point density of about 1 point $/ \mathrm{m}^{2}$. The $x, y$, and $z$ positions (which correspond with the east-west, north-south, and elevation coordinates, respectively), along with the intensities of each pulse, were supplied for the first and last pulse, and geo-referenced to the projection system of the UTM zone: 48N, WGS 84. The accuracy report that accompanied the LiDAR data indicates that accuracy in the $x-y$ position is $0.10 \mathrm{~m}$, and in $z$ position is $0.03 \mathrm{~m}$. Like most discrete return LiDAR systems, the Riegl LMS-Q560 records intensity for each pulse in the near infrared $(1550 \mathrm{~nm})$ region. The intensity of each return pulse, sometimes referred to as laser amplitude, represents the reflected energy from a highly culminated beam of light (i.e., the light's footprint semidiameter is $0.20 \mathrm{~m}$ if the sensor's operating height is $800 \mathrm{~m}$ ) and provides a concentrated measurement of the object's reflectivity. 
Figure 1. The location of the study area (a) The top left corner shows a map of China, in which the yellow area is the location of the Gansu province. The yellow area is the map of Gansu, in which the red square marks the Dayekou area's location; (b) The high resolution color charge coupled device (CCD) image (RGB (red, green, and blue) composition) of Dayekou, in which the red flags mark the forest sample plots; there is no data in the white area.
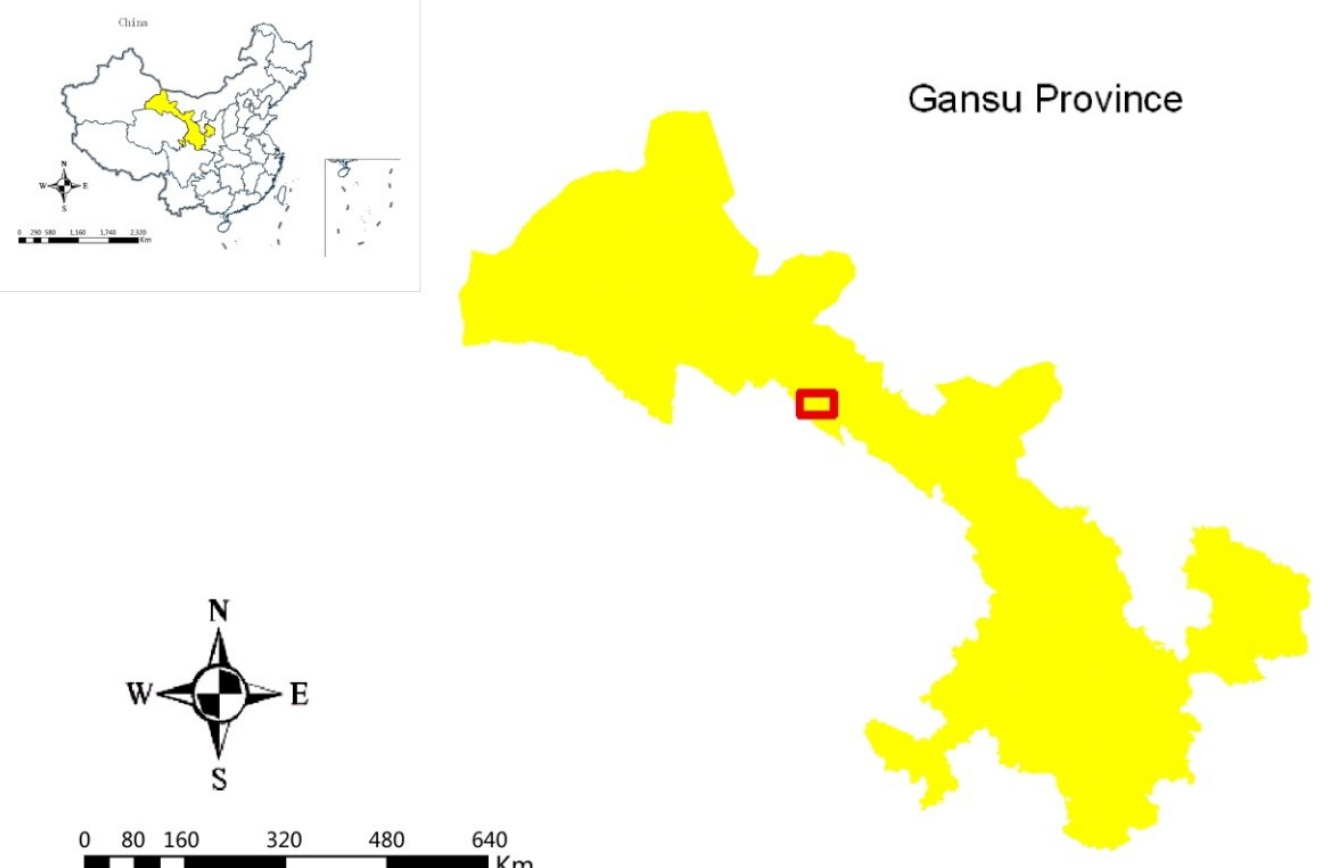

(a)

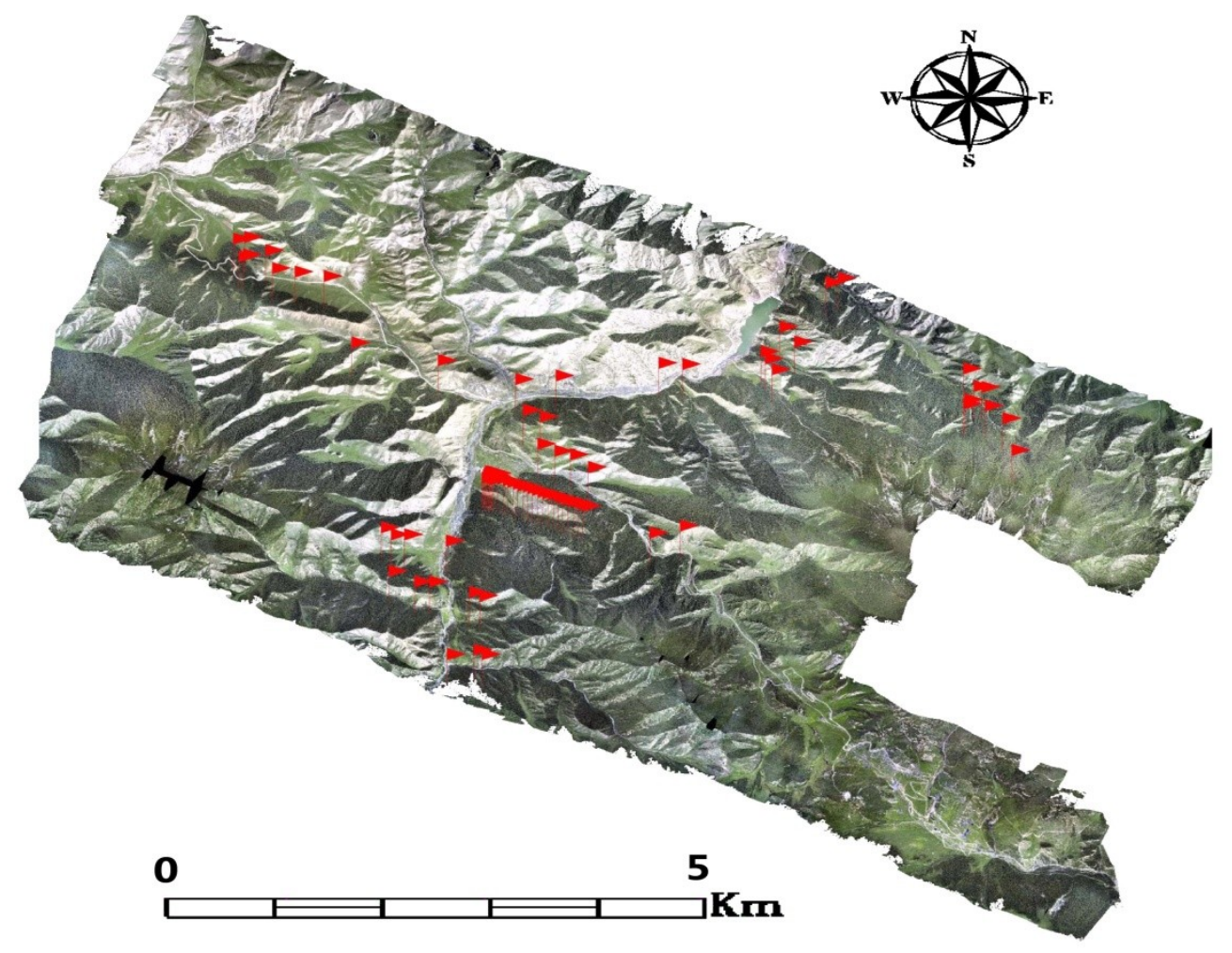

(b) 


\subsection{Plot Measurements}

In order to investigate the capability of LiDAR data for forest biomass estimation, ground truth data were collected through field work from July to August of 2007, and from June to July of 2008. A high resolution airborne CCD image mosaic was used to identify each forest stand through manual interpretation. Some forest stands were selected for field plot data measurement. The size of sample plots was limited to either $20 \mathrm{~m} \times 20 \mathrm{~m}$ or $25 \mathrm{~m} \times 25 \mathrm{~m}$. The height $(\mathrm{H})$ and diameter at the breast height of $1.3 \mathrm{~m}(\mathrm{DBH})$ of each individual tree within each plot was measured. The DBH was defined as the ground truth data on the plot level. For the plots, the plots mean DBH ranged from $5.56 \mathrm{~cm}$ to $26.66 \mathrm{~cm}$, with an average value of $15.55 \mathrm{~cm}$; the mean tree height ranged from $3.16 \mathrm{~m}$ to $16.72 \mathrm{~m}$, with an average value of $9.59 \mathrm{~m}$. A set of total 83 forest sample plots was selected from the measurement database by the following criteria: plot location fixed with a differential GPS system; prevalence of forest plots dominated by Picea crassifolia; forest plots that are independent from one another (to avoid the spatial autocorrelation). The forest sample plots distribution is shown in Figure 1.

\subsection{Field-Based Biomass Estimates}

Using relative allometric Equations (1)-(4) [24], tree biomass components (e.g., stem, branch, foliage, and fruit) were calculated from DBH and total height. Similar allometric equations using the variable of $\mathrm{DBH}^{2} \mathrm{H}$ to estimate forest biomass and biomass components could be found in other studies [25-27]. Tree component biomass values were calculated for individual tree within each plot, and then summed to obtain a summary of tree biomass for each plot. Crown biomass was equal to the sum of branch, foliage, and fruit biomasses. Above-ground biomass was equal to the sum of the crown and stem biomasses.

$$
\begin{gathered}
\text { Stem_biomass }=0.0478 \times\left(D B H^{2} \times H\right)^{0.8665} \\
\text { Branch_biomass }=0.0061 \times\left(D B H^{2} \times H\right)^{0.8905} \\
\text { Foliage_biomass }=0.2650 \times\left(D B H^{2} \times H\right)^{0.4701} \\
\text { Fruit_biomass }=0.0342 \times\left(D B H^{2} \times H\right)^{0.5779}
\end{gathered}
$$

\subsection{Calculation of LiDAR Metrics}

Figure 2 shows the main LiDAR processing steps used in this study. The steps are illustrated in a flow chart. The first step involves the elimination of pulses identified as below the nominal ground surface, or above the expected canopy height. The remaining pulses were divided into those that reached the ground surface and those that did not. Ground hits were removed using Terrascan and MicroStation software. This algorithm identified ground hits based on an iterative slope analysis of LiDAR returns [28]. Grid cell size and the maximum slope of the area were required input parameters. Grid cell size is the smallest cell size for which a ground return can be extracted. In this paper, Grid cell size and the maximum slope of the area were set at $30 \mathrm{~m}$ and $88 \%$, respectively. After, ground points were used to generate a ground digital terrain model (DTM) [29]. First, a triangulated irregular 
network (TIN) was constructed for the point cloud, based on a Delaunay triangulation of its elevation data. Then, a rectangular grid of pixels was extracted from each TIN using linear interpolation with a constant sampling interval of one meter. Finally, a raster DTM was generated with $0.5 \mathrm{~m} \times 0.5 \mathrm{~m}$ spatial resolution. To assess the accuracy of extracted ground hits, the DTM created by the ground hits was compared with the points measured with the total station. For 1546 compared field measurements, the extremes of the differences between the DTM and total station values are $-95.1 \mathrm{~cm}$ and $+94.8 \mathrm{~cm}$; the mean difference is $-21.8 \mathrm{~cm}$, and the RMSE is $\pm 22.7 \mathrm{~cm}$.

Figure 2. The main LiDAR processing steps in this study are illustrated in a flow chart.

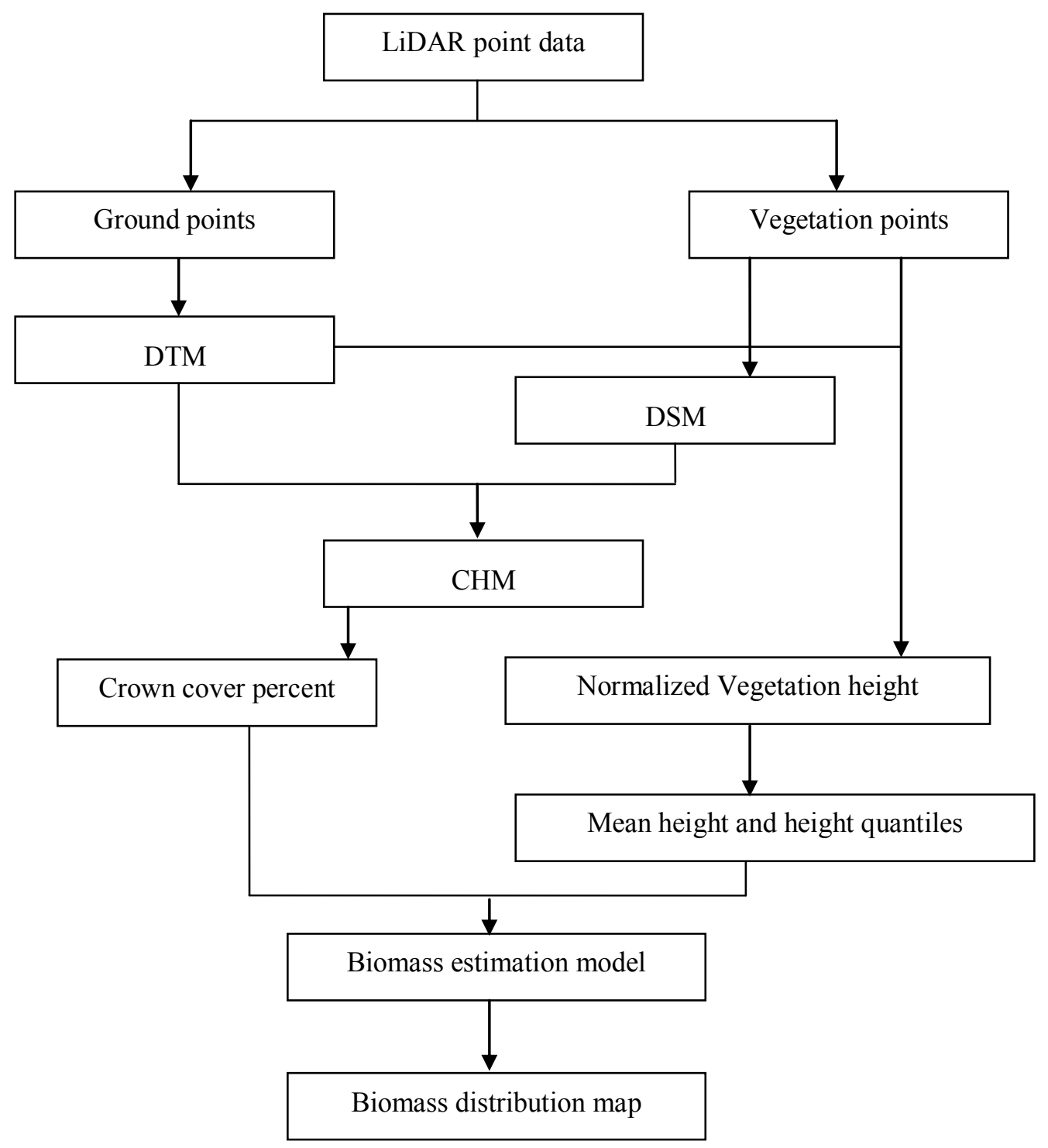

Nonground hits, designated as vegetation hits, were normalized for varying terrain elevations, thereby enabling volume and biomass models to incorporate actual LiDAR point heights [30]. This was done by calculating the actual return height above a LiDAR-derived 0.5-m DTM of the study area. The actual height of each vegetation point was calculated as the difference between the vegetation hit and the bilinear interpolated height of the four corner cells of the DTM cell directly beneath each hit. Typically, a small shrub can grow up to about $1.3 \mathrm{~m}$ in height. Consequently, only returns with an actual height above this threshold were associated with woody vegetation. 
As above-ground biomass estimation is most sensitive to tree height. The major independent variables for stepwise multiple regression in this study were the mean height and height quantiles from LiDAR points [31,32]. The quantile describes the distribution and location of the sample, and is expressed as:

$$
p\left(x \leq \theta_{p}\right)=p
$$

where $p\left(X \leq \theta_{p}\right)$ is the cumulative distribution function, $X$ is the population, and $\theta_{p}$ is the quantile of population $X$ at $p(0<p<1)$.

A total of 19 vegetation height quantiles were calculated by sorting the vegetation points in ascending order at each plot, and classifying them into classes at 5\% intervals, ranging from $p=5 \%$ to $p=95 \%$.

Crown cover (CC) was selected as another statistical variable. To generate equivalent CC estimates from LiDAR data, returns greater than $1.3 \mathrm{~m}$ in height were considered as tree crown elements. All points were interpolated into a raster image. When the grid unit had multiple echoes, the maximum value was selected as the interpolation value. According to the point cloud density, the digital surface model (DSM) was interpolated into a resolution of $0.5 \mathrm{~m}$. The canopy height model (CHM) was obtained to indicate the difference between the DSM and DTM. The $1.3 \mathrm{~m}$ height threshold was used to conform to definitions of forest cover, with all $0.5 \times 0.5$ pixels above this threshold coded as either 1 or 0 . For each field plot, crown cover percentage (CC \%) was calculated as the sum of all cells with a value of 1 as a percentage of the total. The result was assessed in [33]; the $R^{2}$ between the retrieved $\mathrm{CC} \%$ values and those measured by Hemiview is 0.3901 .

Finally, these variables were selected for forest biomass estimation. To select the most significant variables for biomass estimation from these variables including mean height, height quantiles, and $\mathrm{CC}$, stepwise multiple linear regressions were used.

\subsection{Statistical Analysis}

Parametric estimation via the multiple linear regression method was conducted for LiDAR data. The metrics follow a normal distribution, and from the scatter plot, we determined that a linear regression was suitable. The literature has been consistent with these conclusions $[4,30,34,35]$. Considering that 21 possible independent variables may be used in the regression, based on statistical variables of LiDAR data, a stepwise multiple linear regression method was used alternatively to select the most significant variables (probability of F-to-enter $=0.05$; probability of F-to-remove $=0.1$ ).

The conventional multivariate regression model can be expressed as follows:

$$
\hat{Y}=a_{0}+a_{1} X_{1}+\ldots+a_{i} X_{i}
$$

where $\hat{Y}$ is the dependent parameter to be predicted, $X_{0}$ is the intercept, $i$ is the number of independent variables, and $a_{1 \ldots i}$ and $X_{1 \ldots i}$ are the regression coefficients and values of independent variables, respectively. In this study, $\hat{Y}$ refers to the forest biomass components and above-ground biomass, $X_{1 \ldots i}$ are the mean heights, height quantiles, and $\mathrm{CC}$ values. Collinearity was diagnosed through the Variance Inflation Factor (VIF). Generally, if the VIF is less than 10, collinearity is not serious [4,36]. 
Some sample data were used for estimation, while the rest were used for validation. The estimation accuracy was calculated as follows:

$$
\text { Accuracy }=1-\frac{\mid \text { field forest parameter }- \text { estimated forest parameter } \mid}{\text { field forest parameter }}
$$

\section{Results}

\subsection{Biophysical Parameters Description}

Ground-based above-ground biomass components are calculated using field-measured heights and DBH values; the component values are presented in Table 1. The above-ground biomass ranges from 17.89 to $174.88 \mathrm{Mg} \cdot \mathrm{ha}^{-1}$, with a mean value of $104.53 \mathrm{Mg} \cdot \mathrm{ha}^{-1}$, and a standard deviation of $33.86 \mathrm{Mg} \mathrm{ha}^{-1}$. From Table 1, we can see that the stem, crown, and above-ground biomass have large standard deviations, while branch, foliage, and fruit biomass have comparatively smaller standard deviations. Above-ground biomass ranges from $17.89 \mathrm{Mg} \cdot \mathrm{ha}^{-1}$ for young plantation stands, to $174.88 \mathrm{Mg} \cdot \mathrm{ha}^{-1}$ for mature, highly stocked stands. On average, $72 \%$ of the total above-ground biomass of a tree is contained within the stem, $11 \%$ in branches, $13 \%$ in the foliage, and $4 \%$ in fruit.

\subsection{Regression Models between Biomass and LiDAR Metrics}

Stepwise multiple regression analysis is used to establish the above-ground biomass and biomass components equation, and the results are shown in Table 2. Scatter plots plotting above-ground biomass and biomass components against their significant variables are shown in Figure 3. These models with a significance level of 0.01 can be used for forest parameters estimation. Sixty sample data plots were used to build the equation, and the remaining 23 plots were used for validation. The LiDAR-measured variables that proved significant for predicting stem biomass, branch biomass, and above-ground biomass were mean height and CC. Stem, branch, and above-ground biomasses had adjusted $R^{2}$ values of $0.748,0.749$, and 0.727 , respectively, RMSE values of 9.876, 1.520, and 15.237 $\mathrm{Mg} \cdot \mathrm{ha}^{-1}$, and relative RMSE values of $12.783 \%, 12.423 \%$, and $14.163 \%$, respectively. Also, the VIF for mean height and $\mathrm{CC}$ is 1.003 , thus indicating an absence of collinearity. Figure $3 \mathrm{a}-\mathrm{d}, \mathrm{k}, 1$ shows the scatter plots plotting stem biomass, branch biomass, and above-ground biomass against mean height and CC. From these scatter plots, it is shown that in comparison with CC, mean height more strongly correlates with stem biomass, branch biomass, and above-ground biomass. The LiDAR-measured variable that proves significant for predicting foliage biomass is $\mathrm{H} 5$ (i.e., the $5 \%$ vegetation height quantile), which has an adjusted $R^{2}$ of 0.356 , an RMSE of $3.691 \mathrm{Mg} \cdot \mathrm{ha}^{-1}$, and a relative RMSE of $26.953 \%$. Figure $3 \mathrm{e}$ shows the scatter plots between foliage biomass and H5. The LiDAR-measured variables that prove significant for predicting fruit biomass are the mean and H85 values (i.e., the $85 \%$ vegetation height quantile). Together, these variables have an adjusted $R^{2}$ of 0.578 , an RMSE of $1.022 \mathrm{Mg} \mathrm{ha}^{-1}$, and a relative RMSE of $23.273 \%$. The VIF for the mean and H85 is 7.961, which means that there is no collinearity. Figure 3f,g shows the scatter plots plotting fruit biomass against mean height and H85. From the scatter plots, it is shown that mean height more strongly correlates with fruit biomass than H85 does. The LiDAR-measured variables that prove significant for predicting crown biomass are the mean, H85, and CC. These variables together have an 
adjusted $R^{2}$ of 0.648 , an RMSE of $5.963 \mathrm{Mg} \mathrm{ha}^{-1}$, and a relative RMSE of $19.665 \%$. The VIFs for the mean, H85, and $\mathrm{CC}$ are 8.577, 8.561, and 1.079, respectively. Thus, none of these variables are collinear. Figure $3 \mathrm{~h}-\mathrm{j}$ shows scatter plots plotting crown biomass against mean height, H85, and CC. From the scatter plots, it is shown that the mean height most strongly correlates with crown biomass, and that $\mathrm{CC}$ has the weakest relationship with crown biomass. Stem and branch biomass values most strongly correlate with the LiDAR data, while foliage biomass has the weakest relationship with the LiDAR data. The estimation accuracy is shown in Table 3.

\subsection{Spatial Distribution Figure of Forest Biomass}

First of all, the research area is segmented using a $20 \mathrm{~m} \times 20 \mathrm{~m}$ grid. The LiDAR parameters were then measured in each segmented cell; parameters include mean height, height quantiles, and CC. Finally, above-ground biomass and biomass components in each segmented cell can be obtained based on the establishment of the above-ground biomass and biomass components estimation equation. The result is shown in Figure 4. The range of estimated stem, branch, foliage, fruit, crown, and

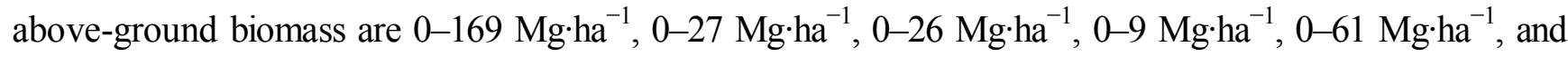
$0-230 \mathrm{Mg} \cdot \mathrm{ha}^{-1}$, respectively.

Table 1. Characteristics of above-ground biomass $\left(\mathrm{Mg} \cdot \mathrm{ha}^{-1}\right)$ and biomass components for in-situ measured plots.

\begin{tabular}{ccccc}
\hline Statistic & Minimum & Maximum & Mean & Standard deviation \\
\hline Stem biomass & 9.80 & 130.82 & 75.19 & 26.02 \\
Branch biomass & 1.41 & 21.00 & 11.92 & 4.21 \\
Foliage biomass & 2.92 & 22.87 & 13.19 & 3.47 \\
Fruit biomass & 0.87 & 6.85 & 4.23 & 1.17 \\
Crown biomass & 5.68 & 44.42 & 29.34 & 8.23 \\
Above-ground biomass & 17.89 & 174.88 & 104.53 & 33.86 \\
\hline
\end{tabular}

Table 2. Stepwise multiple regression results for above-ground biomass and individual biomass components.

\begin{tabular}{cccccc}
\hline & Variables & Std & $\boldsymbol{R}^{2}$ & Adjusted $\boldsymbol{R}^{2}$ & Model \\
\hline Stem biomass & Mean, CC & 13.823 & 0.756 & 0.748 & $-13.595+8.446 \mathrm{Mean}+20.378 \mathrm{CC}$ \\
Branch biomass & Mean, CC & 2.229 & 0.757 & 0.749 & $-2.447+1.367 \mathrm{Mean}+3.300 \mathrm{CC}$ \\
$\begin{array}{c}\text { Foliage biomass } \\
\text { Fruit biomass }\end{array}$ & H5 & 2.692 & 0.366 & 0.356 & $7.767+0.861 \mathrm{H} 5$ \\
Mean, H85 & 9.507 & 0.591 & 0.578 & $1.726+0.541 \mathrm{Mean}-0.210 \mathrm{H} 85$ \\
$\begin{array}{c}\text { Crown biomass } \\
\begin{array}{c}\text { Above-ground } \\
\text { biomass }\end{array}\end{array}$ & Mean, H85, CC & 5.025 & 0.664 & 0.648 & $8.017+4.038 \mathrm{Mean}-1.502 \mathrm{H} 85+$ \\
& Mean, CC & 18.640 & 0.736 & 0.727 & $-9.013+10.812 \mathrm{Mean}+25.105 \mathrm{CC}$ \\
\hline
\end{tabular}


Figure 3. Scatter plots of between above-ground biomass and biomass components and their significant variables. (a) and (b) compare stem biomass against mean height and crown cover, respectively; (c) and (d) plot branch biomass against mean height and crown cover, respectively; (e) is plots foliage biomass against H5; (f) and (g) plot fruit biomass against mean height and H85, respectively; (h), (i) and (j) plot crown biomass against mean height, H85, and crown cover, respectively; (k) and (l) plot above-ground biomass against mean height and crown cover, respectively.

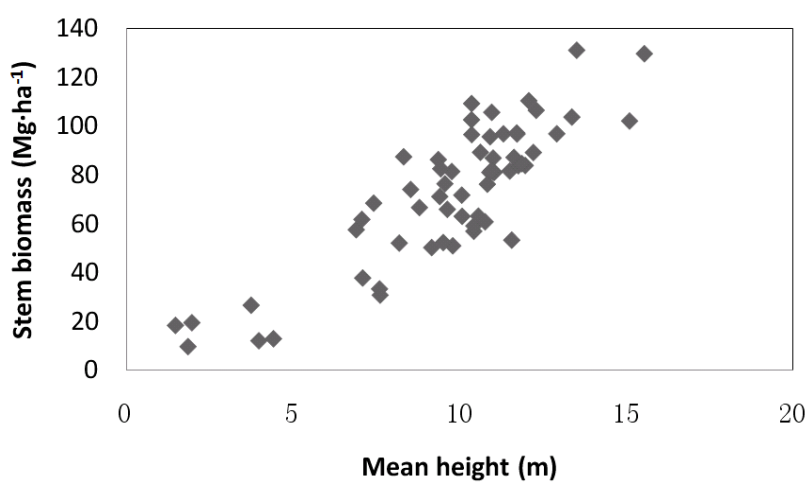

(a)

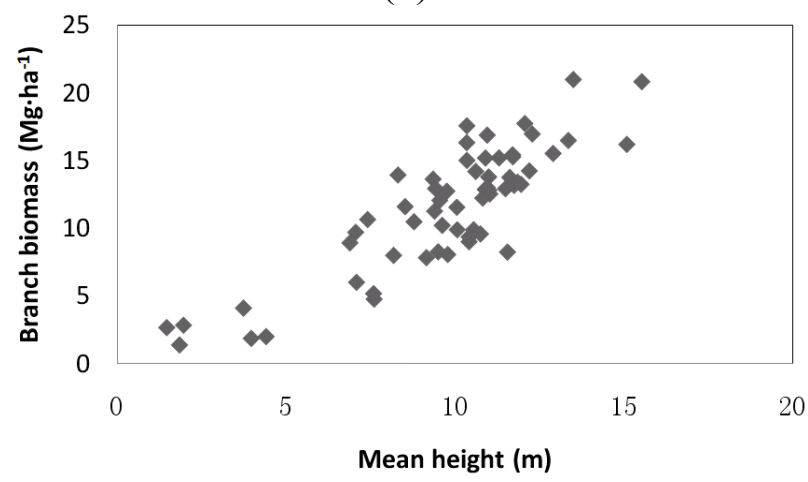

(c)

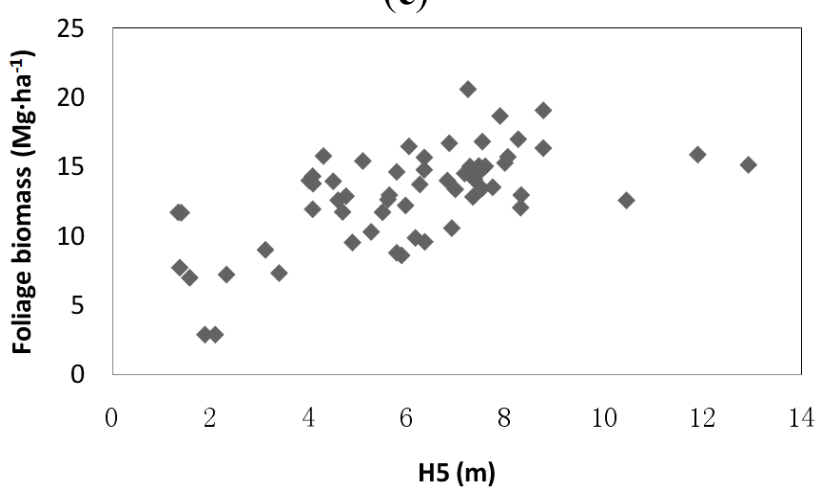

(e)

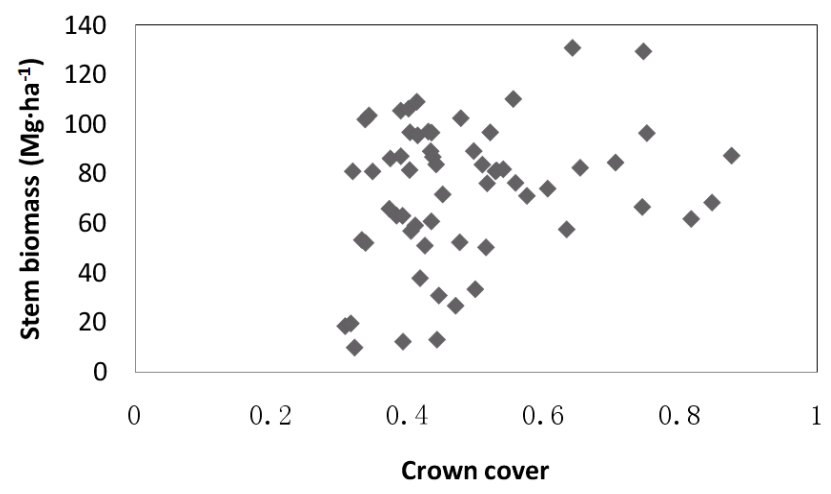

(b)

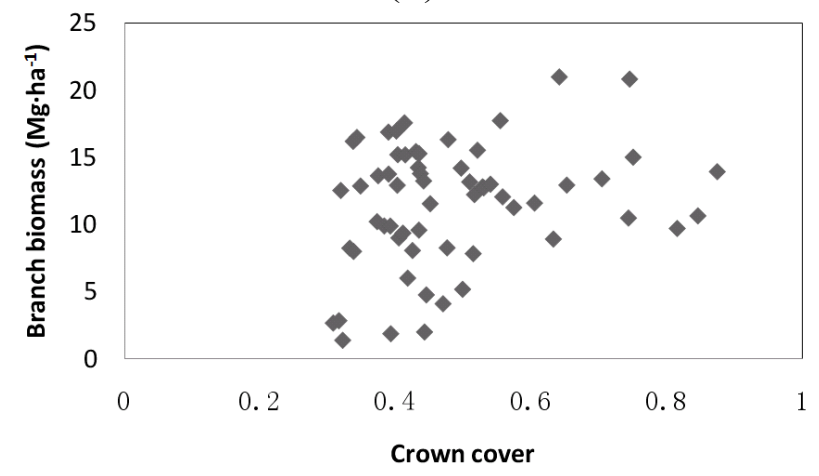

(d)

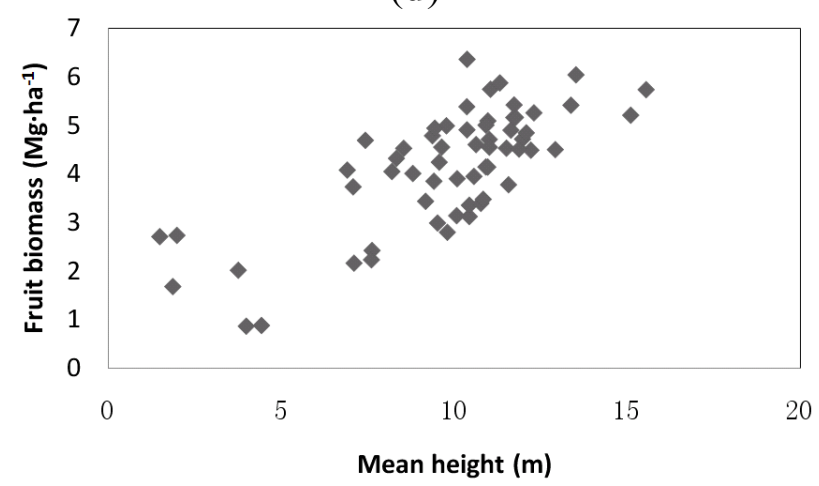

(f) 
Figure 3. Cont.

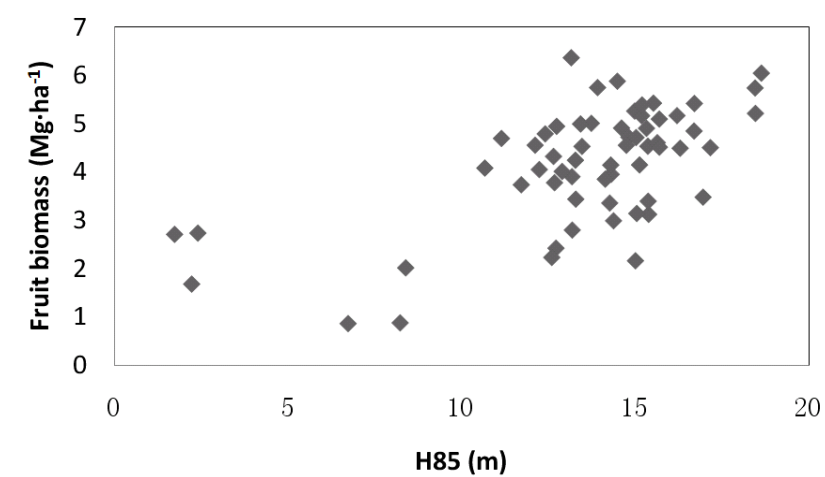

(g)

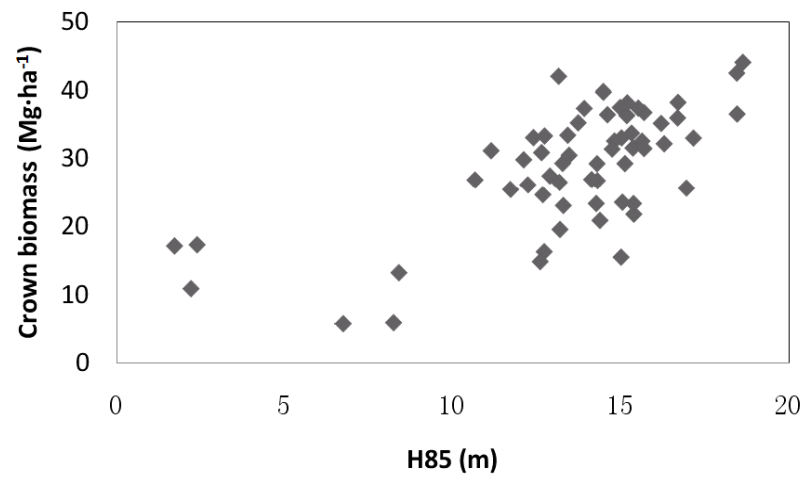

(i)

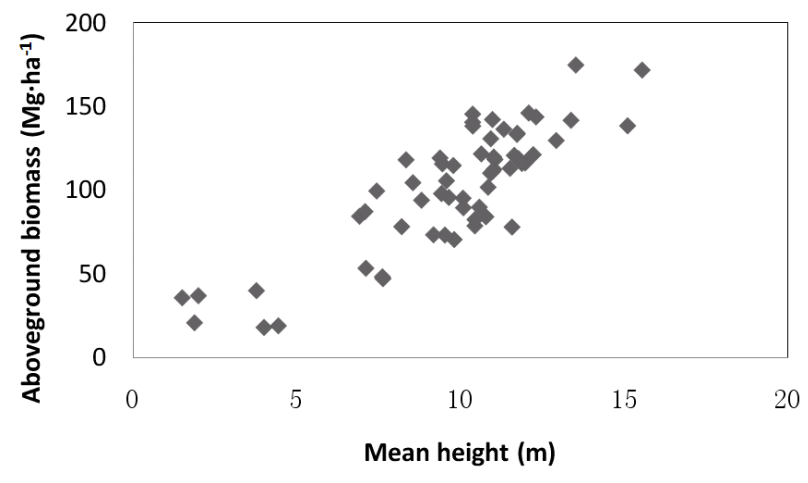

(k)

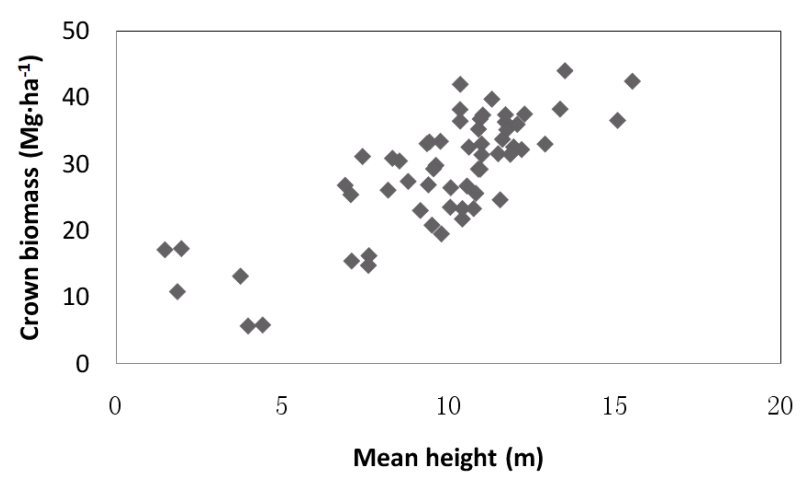

(h)

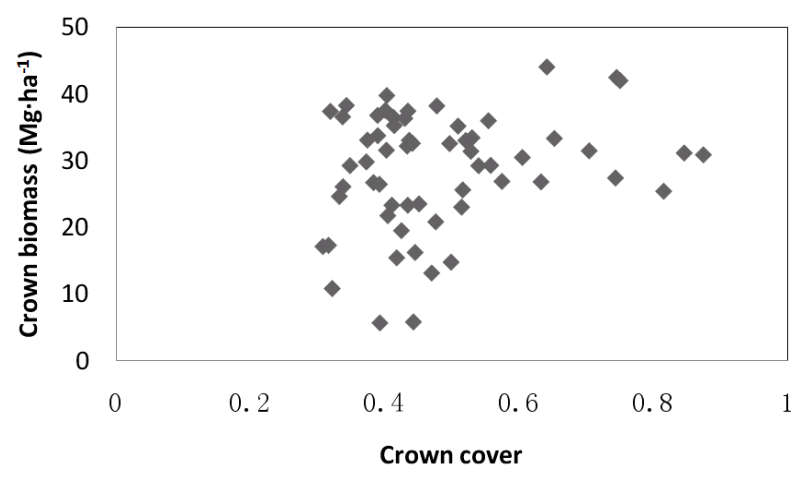

(j)

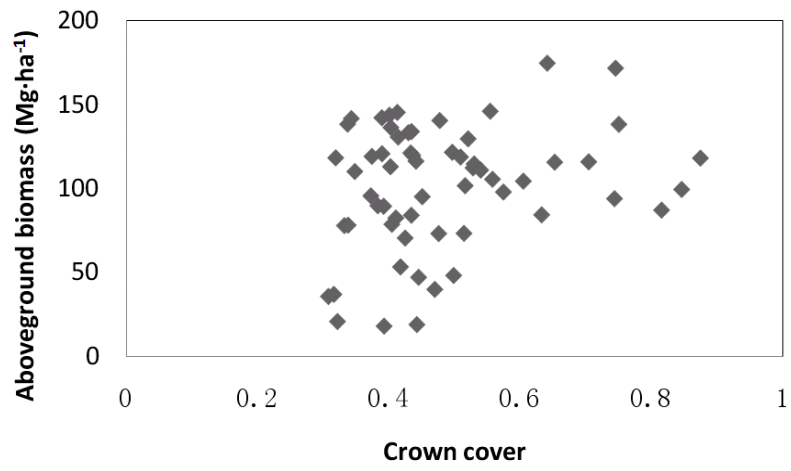

(l)

Table 3. Estimated accuracy of above-ground biomass and individual biomass components; RMSE: root mean squared error.

\begin{tabular}{ccccccc}
\hline Biomass & Stem & Branch & Foliage & Fruit & Crown & Above-ground \\
\hline RMSE $\left({\left.\mathrm{Mg} \cdot \mathrm{ha}^{-1}\right)}^{-1}\right)$ & 9.876 & 1.520 & 3.691 & 1.022 & 5.963 & 15.237 \\
Relative RMSE $(\%)$ & 12.783 & 12.423 & 26.953 & 23.273 & 19.665 & 14.163 \\
Accuracy $(\%)$ & 87.45 & 87.60 & 80.00 & 80.15 & 82.59 & 87.08 \\
\hline
\end{tabular}


Figure 4. Spatial distributions of above-ground biomass and biomass components. (a) Stem biomass; (b) Branch biomass; (c) Foliage biomass; (d) Fruit biomass; (e) Crown biomass; and (f) Above-ground biomass.

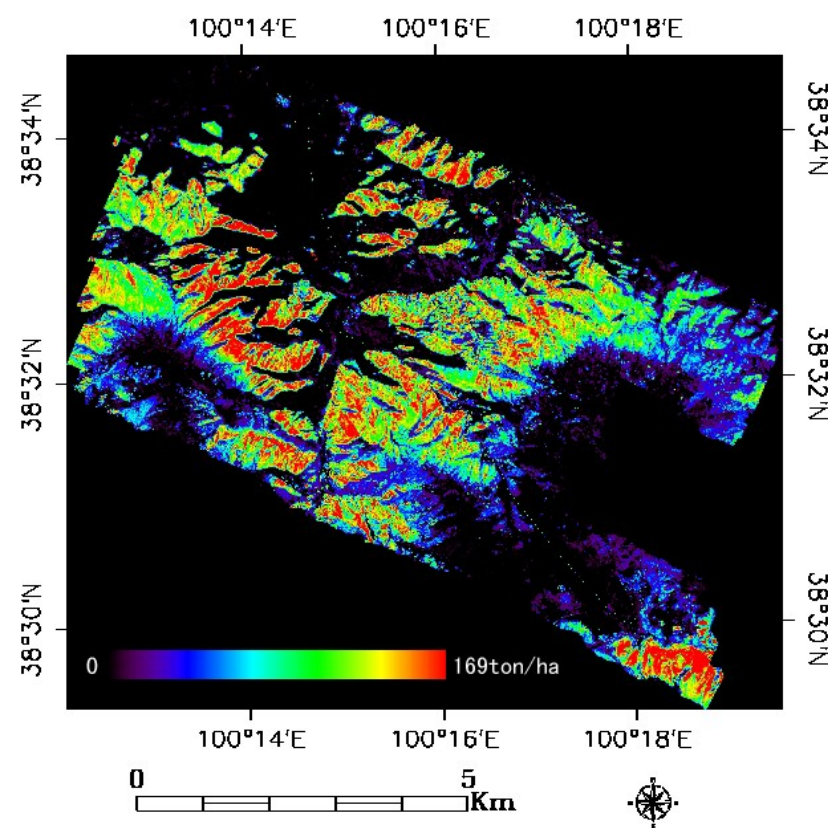

(a)

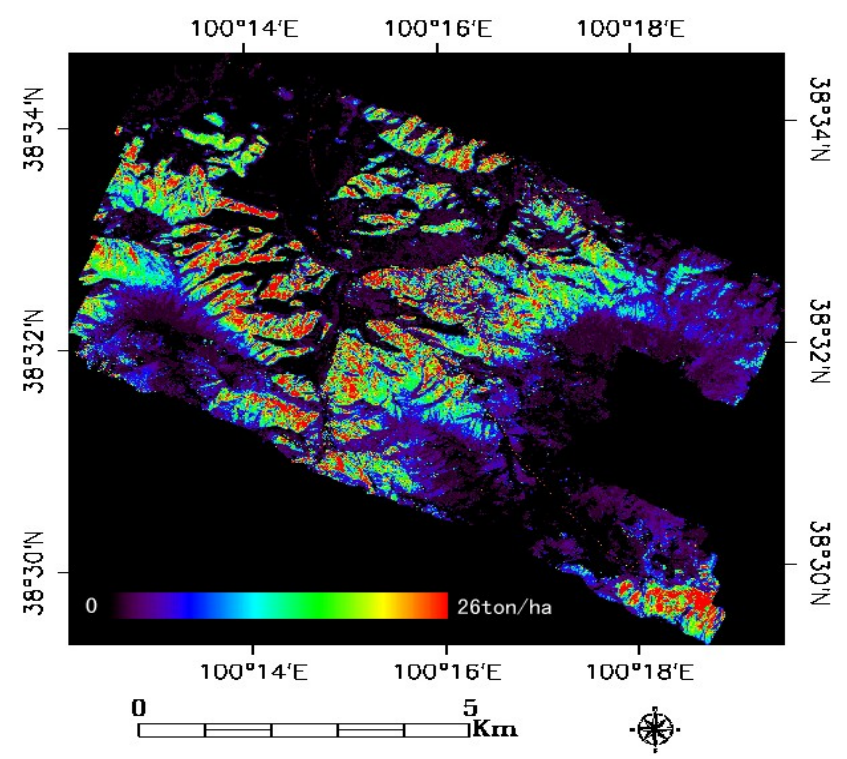

(c)

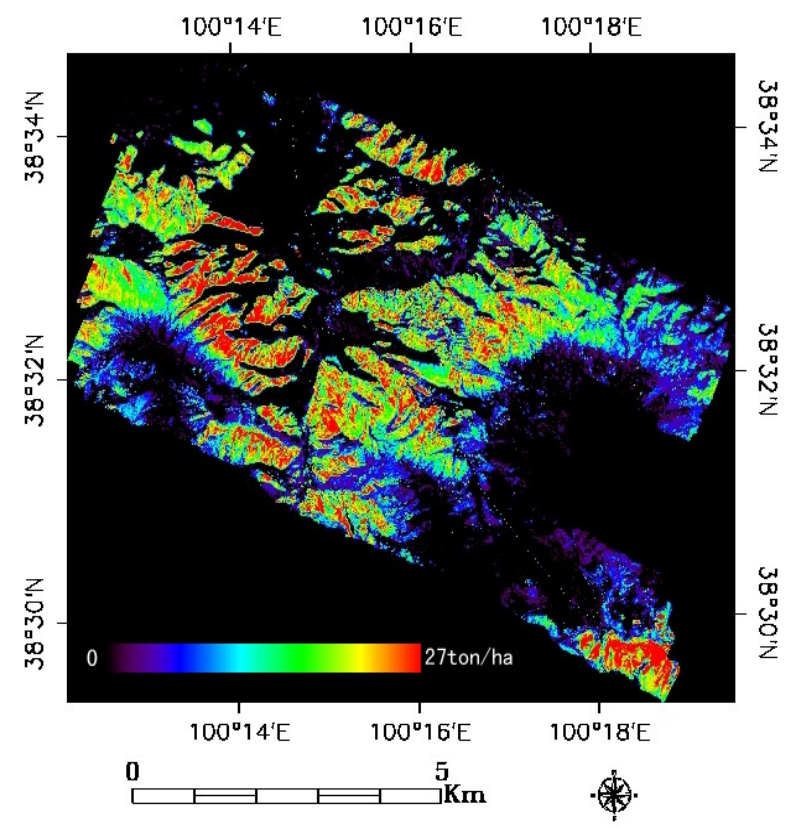

(b)

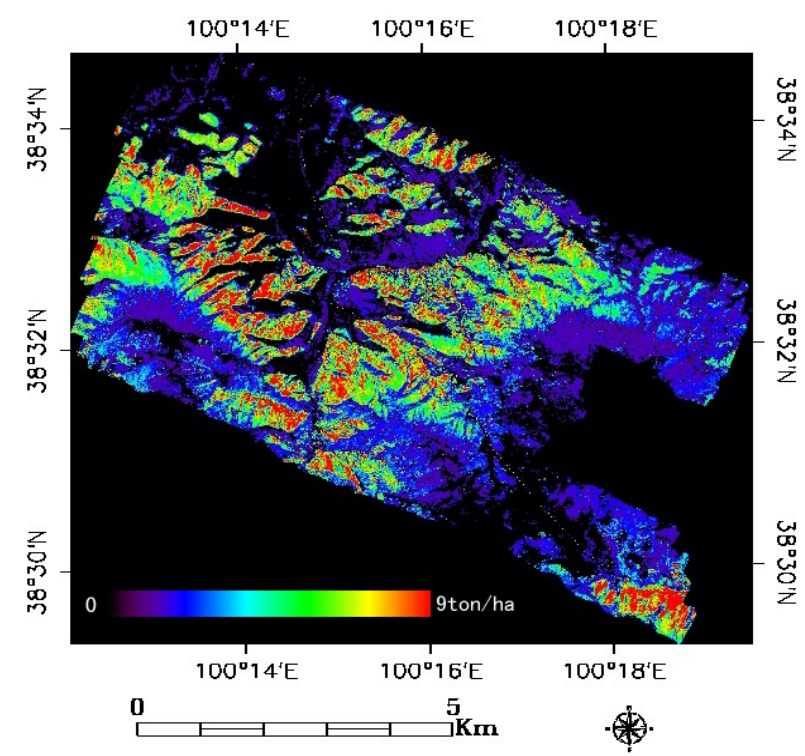

(d) 
Figure 4. Cont.

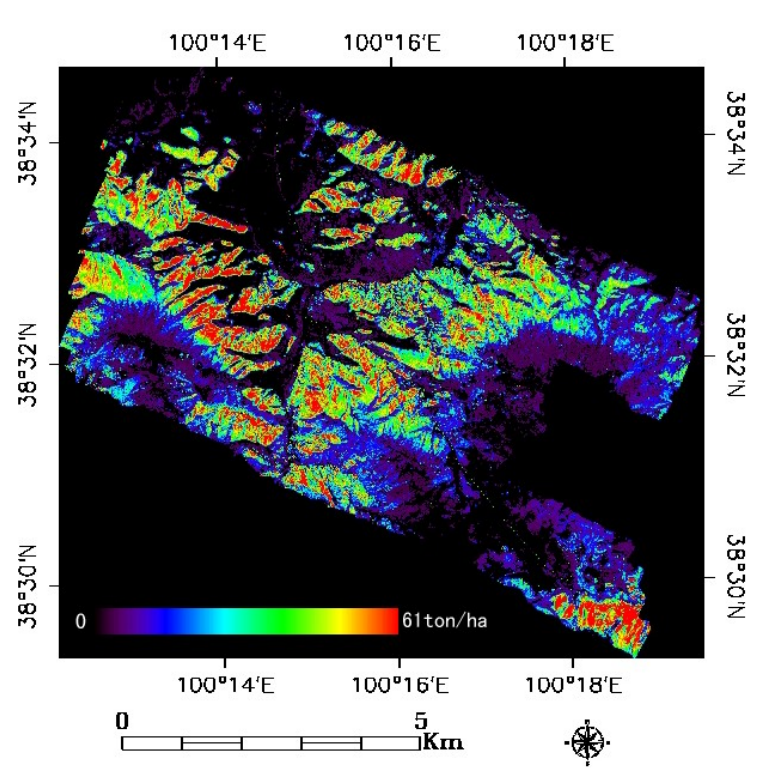

(e)

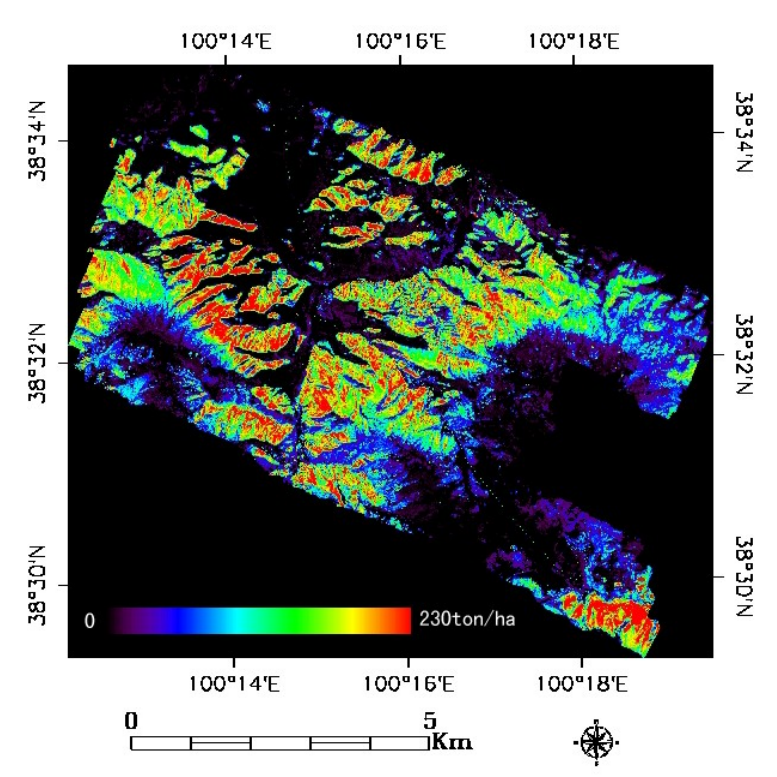

(f)

Figure 5 shows the CCD image together with the DTM, Slope, and Aspect images. From Figure 5, we obtain the scatter plots plotting above-ground biomass against elevation, slope, and aspect (Figure 6). From the extracted above-ground biomass distribution map (Figure 4f) and the DTM (Figure 5b), we observe that the forests exist in altitude ranging from about $2600 \mathrm{~m}$ to $3600 \mathrm{~m}$; the high biomass forests are found at an altitude of about $3000 \mathrm{~m}$ (i.e., from about $2800 \mathrm{~m}$ to $3200 \mathrm{~m}$ ). Above $3200 \mathrm{~m}$, the biomass decreases. Typically, when one ascends a mountain, precipitation increases and the temperature decreases; thus, altitude influences forest distribution. Forests exist where there are higher precipitation and temperatures. Thus, forests exist within an optimum altitude range. For Picea crassifolia, the optimum altitude varies from about $2600 \mathrm{~m}$ to $3600 \mathrm{~m}$. Specifically, from $2800 \mathrm{~m}$ to $3200 \mathrm{~m}$, the precipitation and temperature conditions enable higher levels of Picea crassifolia biomass growth. Also, most forests consist of with a slope varying from 10 to 50 degrees. Little can grow on a slope that is steeper than 50 degrees. Finally, most forests cluster along several azimuths: from 0 to 100 degrees, and from 250 to 360 degrees. From 100 to 350 degrees, most forest biomass quantities are less than $70 \mathrm{Mg} \cdot \mathrm{ha}^{-1}$. Compared with forests that exist in relatively shaded areas, forests existing in relatively sunnier areas receive more solar radiation, which causes dehydration via intense evapotranspiration. Consequently, there is very little biomass in relatively sunnier areas (i.e., areas where the azimuth ranges from about 100 to 250 degrees). 
Figure 5. CCD image together with the DTM, Slope, and Aspect images. (a) CCD image; (b) DTM image; (c) Slope image and (d) Aspect image.

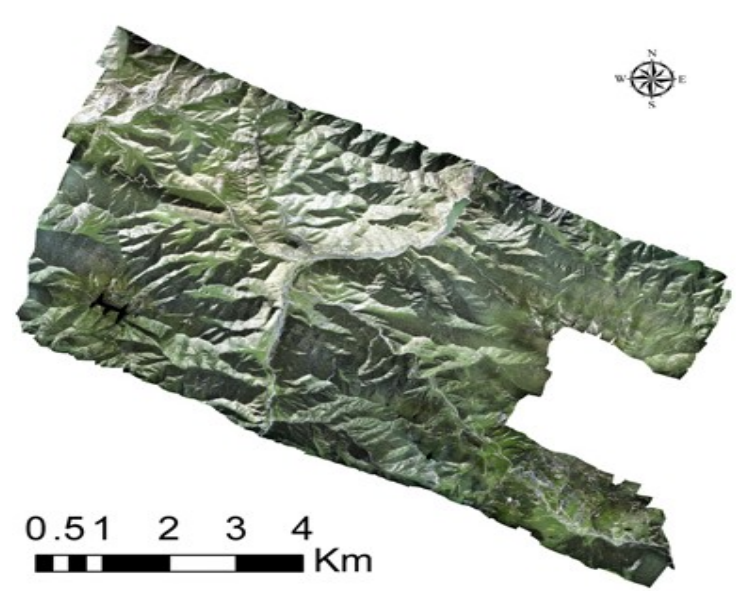

(a) CCD image

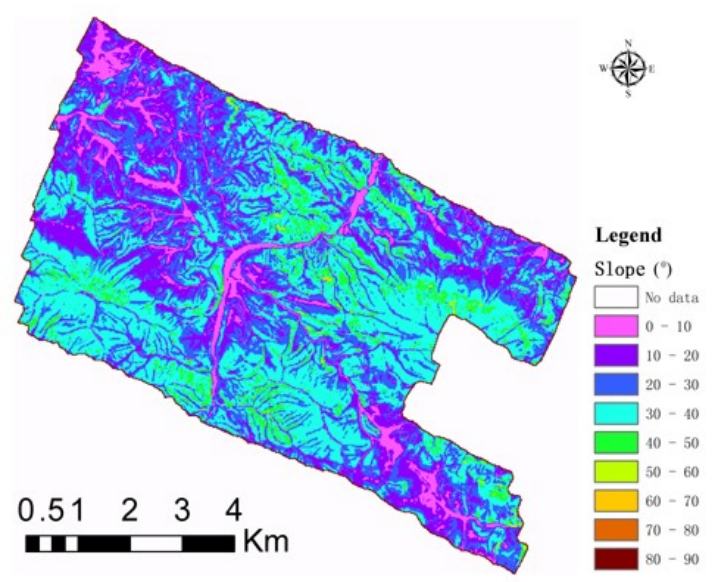

(c) Slope image

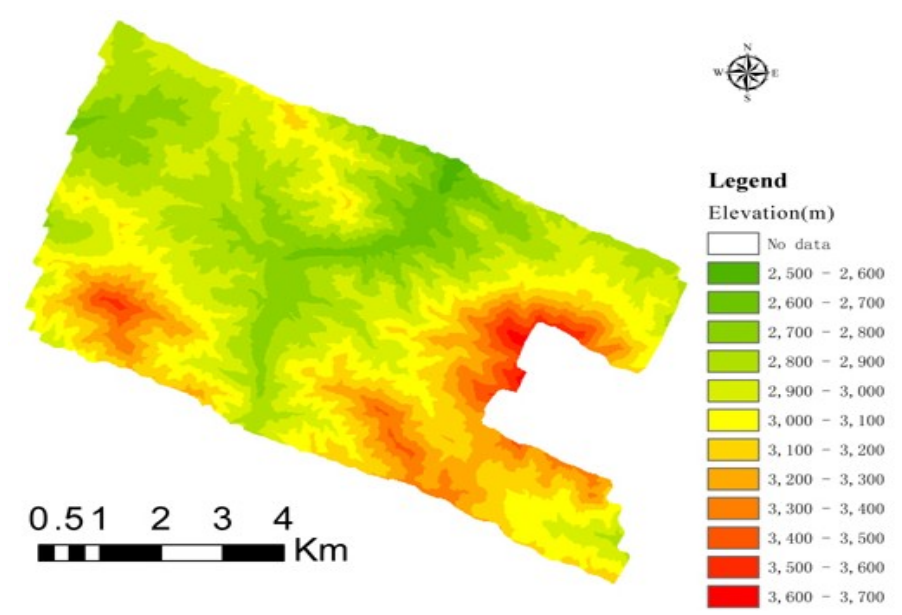

(b) DTM image

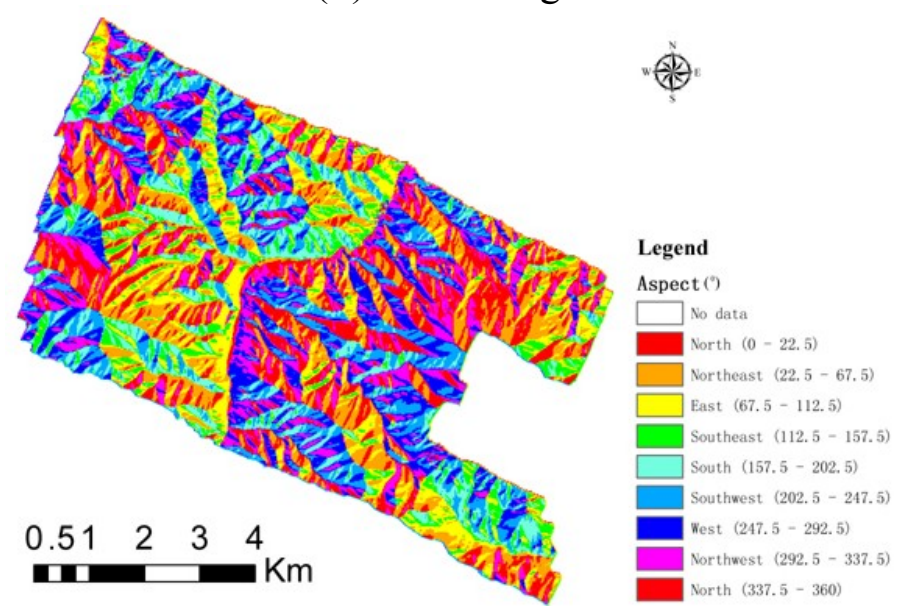

(d) Aspect image

Figure 6. Scatter plots plots comparing above-ground biomass against elevation, slope, and aspect. (a) Scatter plot of the above-ground biomass and elevation; (b) scatter plot of the above-ground biomass and slope; (c) scatter plot of the above-ground biomass and aspect.

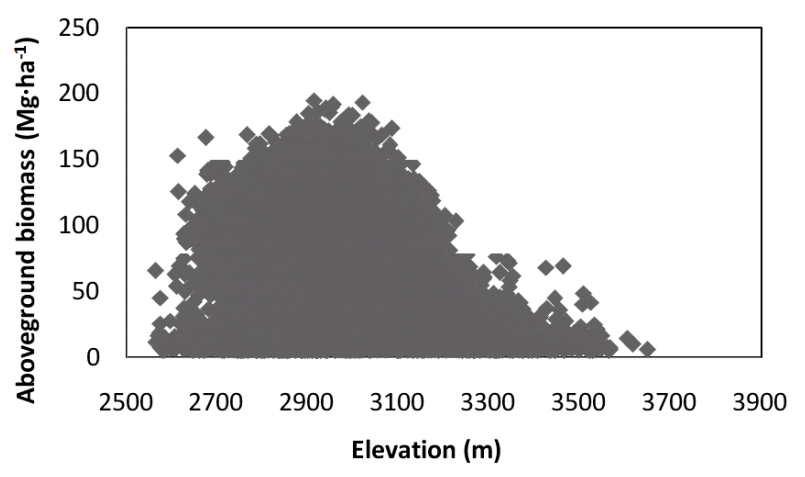

(a)

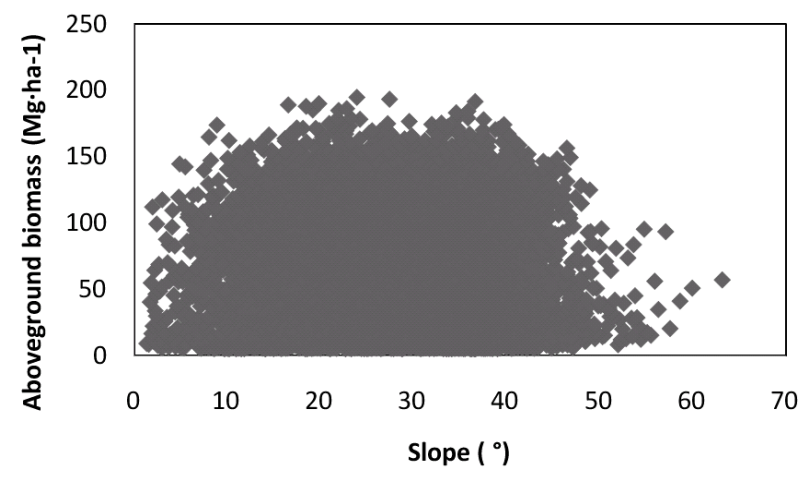

(b) 
Figure 6. Cont.

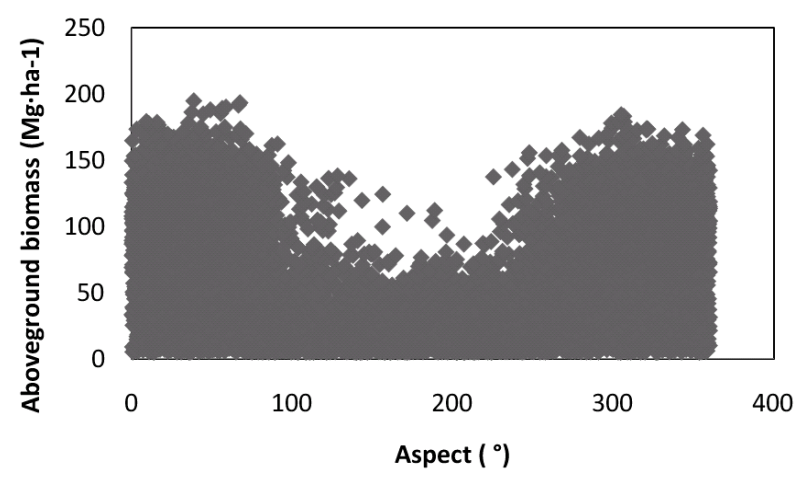

(c)

\section{Discussion and Conclusions}

For biomass estimation using small footprint LiDAR, distributional metrics - such as the mean canopy height and the standard deviation of the canopy height - are taken from either an interpolated grid corresponding to the height of the canopy (i.e., a canopy height model [CHM]) or from raw returns. These metrics are then used in conjunction with regression equations to predict forest properties [31,37,38]. For above-ground biomass and stem biomass, the mean first return height and percentiles (e.g., 10th and 90th) of first return heights were selected as predictor variables from a subset of candidate LiDAR metrics. For crown biomass, the percentage of first returns above $2 \mathrm{~m}$, as well as the 75th and 90th percentiles of first return heights were selected as predictor variables [20]. In this study, the mean height and $\mathrm{CC}$ were selected as predictor variables for above-ground biomass and stem biomass, and the mean height, $\mathrm{CC}$, and the $85 \%$ vegetation height quantile were selected as predictor variables for crown biomass. Although return height and height quantile are often used, the height variables varied for different areas and different biomass components.

In [20], stem, crown, and above-ground biomass were estimated via LiDAR data. Stem biomass correlated most strongly with the LiDAR data, with an adjusted $R^{2}$ of 0.86 and a relative RMSE of $16 \%$. Above-ground biomass showed an adjusted $R^{2}$ of 0.82 , and a relative RMSE of $18 \%$. Crown biomass showed the weakest correlation, with an adjusted $R^{2}$ of 0.72 and a relative RMSE of $22 \%$. Although our results have a lower adjusted $R^{2}$ than the study in [20], we have higher relative RMSE values of 12.783, 14.163, and 19.665 for stem, above-ground, and crown biomass estimates, respectively. The results show that stem biomass, branch biomass, and above-ground biomass estimates have relatively higher accuracies, with adjusted $R^{2}$ values of $0.748,0.749$, and 0.727 , respectively. Also, fruit and crown biomass have relatively higher accuracies, with adjusted $R^{2}$ values of 0.578 and 0.648 , respectively, while foliage biomass has a relative low accuracy with an adjusted $R^{2}$ of 0.356 . Fruit and foliage biomass values/ranges are too low which could be one reason for the weaker relationships. The estimation accuracies for stem biomass, branch biomass, and above-ground biomass exceed $87 \%$, and for fruit, crown, and foliage biomass estimates, the accuracy exceeds $80 \%$. The $R^{2}$ of the equation for estimating stem biomass, branch biomass, and above-ground biomass is greater than 0.7. The LiDAR-measured variables that proved significant for predicting above-ground biomass are mean and $\mathrm{CC}$, which had an adjusted $R^{2}$ of 0.727 . This data compares well in line with 
reality and shows a relatively good result. Biomass is the important parameter because it is an important indicator of the carbon sequestration capacity of forests; such capacity estimates are essential for assessing forest carbon balance. Thus, LiDAR with low density is also an important source of data for studying forest carbon sources.

From the CCD image, together with the DTM, Slope, and Aspect images, we observed that the forest comprises altitudes ranging from about $2600 \mathrm{~m}$ to $3600 \mathrm{~m}$, at slopes varying from 10 to 50 degrees. The shapes of scatter plots plotting above-ground biomass against elevation and slope are similar to normal distribution curves. Most forests exist at azimuths range from 0 to 100 degrees, from 250 to 360 degrees, and from 100 to 350 degrees. The shape of the scatter plots plotting above-ground biomass against azimuth is also similar to a normal distribution. This means that Picea crassifolia can exist in southern azimuths; the reason may be that there are superior hydrothermal conditions in that area. However, the forest biomass is relatively lower compared with those that exist in northern azimuths.

From Figure 4, we can see that above-ground biomass and biomass components have similar spatial distributions. One reason is that there is a single species in this area. Above-ground biomass and biomass components increase with age. Another reason may be that the biomass components (e.g., stem, branch, foliage, and fruit) are all calculated from DBH and total height using a relative allometric equation, which can cause the different biomass components to correlate with each other. From Table 2, we can see that, besides the mean height, $\mathrm{CC}$ is selected as a good predictor in stem biomass, branch biomass, crown biomass, and above-ground biomass estimation regression. $\mathrm{CC}$ is a supplementary variable for biomass estimation, and $\mathrm{CC}$, to some extent, represents tree density. As for date acquisition, maybe the leaf-on condition has a higher accuracy than the leaf-off condition because under leaf-off conditions, CC estimation would become difficult and inaccurate. In this study, a point density of 1 point per $\mathrm{m}^{2}$ is used. In another's study [31], a point density of 0.5 points per $\mathrm{m}^{2}$ was sufficient for estimating forest inventory variables at the plot and stand levels for various forest types.

In this paper, we investigated a Picea crassifolia forest stand in the Dayekou area of Qilian Mountain, western China, and used low-density LiDAR point cloud data. Stepwise multiple regression models were used to develop equations relating vegetation point statistics, including height quantiles, mean height, and fractional cover, with field inventory data and field-based estimates of biomass for each sample plot. These results show that low density LiDAR data is useful for forest above-ground biomass and biomass component estimations. Spatial forest above-ground biomass and biomass components were established using stepwise multiple regression equations. These biomass component maps provide additional information for ecosystem management and timber supply. Also, crown biomass can aid in fuel load assessments and fire management strategies. These maps are very useful for updating and modifying forest base maps and registries.

\section{Acknowledgments}

This paper has been supported jointly by the Natural Science Foundation of China (Grant No. 41101308, 41101374 and 41271361), the Fundamental Research Funds for the Central Universities (Grant No. 2011B06714), and the National Science and Technology Support Plan During the 12th Five-year Plan Period of China (2012BAC19B03; 2013BAC10B01). The authors also wish to thank all 
people who participated in the field experiment. The authors also wish to thank all the people that have given helped prepare this paper. The authors are sincerely grateful to the four anonymous reviewers for the constructive and insightful comments which improved this study.

\section{Conflicts of Interest}

The authors declare no conflict of interest.

\section{References}

1. Zhao, F.; Guo, Q.; Kelly, M. Allometric equation choice impacts Lidar-based forest biomass estimates: A case study from the Sierra National Forest, CA. Agric. For. Meteorol. 2012, 165, 64-72.

2. Salas, C.; Ene, L.; Gregoire, T.G.; Naesset, E.; Gobakken, T. Modelling tree diameter from airborne laser scanning derived variables: A comparison of spatial statistical models. Remote Sens. Environ. 2010, 114, 1277-1285.

3. Ahmed, R.; Siqueira, P.; Hensley, S. A study of forest biomass estimates from Lidar in the northern temperate forests of New England. Remote Sens. Environ. 2013, 130, 121-135.

4. Allouis, T.; Durrieu, S.; Vega, C.; Couteron, P. Stem volume and above-ground biomass estimation of individual pine trees from LiDAR data: Contribution of full-waveform signals. IEEE J. Sel. Top. Appl. Earth Obs. Remote Sens. 2013, 6, 924-934.

5. Ene, L.T.; Naesset, E.; Gobakken, T.; Gregoire, T.G.; Stahl, G.; Holm, S. A simulation approach for accuracy assessment of two-phase post-stratified estimation in large-area LiDAR biomass surveys. Remote Sens. Environ. 2013, 133, 210-224.

6. Popescu, S.C.; Zhao, K.; Neuenschwander, A.; Lin, C. Satellite Lidar vs. small footprint airborne lidar: Comparing the accuracy of aboveground biomass estimates and forest structure metrics at footprint level. Remote Sens. Environ. 2011, 115, 2786-2797.

7. Kankare, V.; Vastaranta, M.; Holopainen, M.; Raety, M.; Yu, X.; Hyyppa, J.; Hyyppa, H.; Alho, P.; Viitala, R. Retrieval of forest aboveground biomass and stem volume with airborne scanning LiDAR. Remote Sens. 2013, 5, 2257-2274.

8. Wulder, M.A.; White, J.C.; Nelson, R.F.; Naesset, E.; Orka, H.O.; Coops, N.C.; Hilker, T.; Bater, C.W.; Gobakken, T. LiDAR sampling for large-area forest characterization: A review. Remote Sens. Environ. 2012, 121, 196-209.

9. Kim, Y.; Chang, A.; Kim, Y.; Song, J.; Kim, C. Estimation of forest biomass from airborne LiDAR data as measures against Global Warming-Individual Tree Unit and Forest Stand Unit. Disaster Adv. 2012, 5, 295-299.

10. D’Oliveira, M.V.N.; Reutebuch, S.E.; McGaughey, R.J.; Andersen, H.-E. Estimating forest biomass and identifying low-intensity logging areas using airborne scanning Lidar in Antimary State Forest, Acre State, Western Brazilian Amazon. Remote Sens. Environ. 2012, 124, 479-491.

11. Gonzalez, P.; Asner, G.P.; Battles, J.J.; Lefsky, M.A.; Waring, K.M.; Palace, M. Forest carbon densities and uncertainties from LiDAR, QuickBird, and field measurements in California. Remote Sens. Environ. 2010, 114, 1561-1575. 
12. Sexton, J.O.; Bax, T.; Siqueira, P.; Swenson, J.J.; Hensley, S. A comparison of Lidar, radar, and field measurements of canopy height in pine and hardwood forests of southeastern North America. For. Ecol. Manag. 2009, 257, 1136-1147.

13. Nelson, R.F.; Hyde, P.; Johnson, P.; Emessiene, B.; Imhoff, M.L.; Campbell, R.; Edwards, W. Investigating RaDAR-LiDAR synergy in a North Carolina pine forest. Remote Sens. Environ. 2007, 110, 98-108.

14. Hajnsek, I.; Kugler, F.; Lee, S.-K.; Papathanassiou, K.P. Tropical-forest-parameter estimation by means of Pol-InSAR: The INDREX-II campaign. IEEE Trans. Geosci. Remote Sens. 2009, 47, 481-493.

15. Asner, G.P.; Mascaro, J.; Muller-Landau, H.C.; Vieilledent, G.; Vaudry, R.; Rasamoelina, M.; Hall, J.S.; van Breugel, M. A universal airborne LiDAR approach for tropical forest carbon mapping. Oecologia 2012, 168, 1147-1160.

16. He, Q.-S.; Cao, C.-X.; Chen, E.-X.; Sun, G.-Q.; Ling, F.-L.; Pang, Y.; Zhang, H.; Ni, W.-J.; $\mathrm{Xu}, \mathrm{M}$; Li, Z.-Y.; et al. Forest stand biomass estimation using ALOS PALSAR data based on LiDAR-derived prior knowledge in the Qilian Mountain, western China. Int. J. Remote Sens. 2012, 33, 710-729.

17. Santos, J.R.; Freitas, C.C.; Araujo, L.S.; Dutra, L.V.; Mura, J.C.; Gama, F.F.; Soler, L.S.; Sant'Anna, S.J.S. Airborne P-band SAR applied to the aboveground biomass studies in the Brazilian tropical rainforest. Remote Sens. Environ. 2003, 87, 482-493.

18. Lambert, M.C.; Ung, C.H.; Raulier, F. Canadian national tree aboveground biomass equations. Can. J. For. Res. 2005, 35, 1996-2018.

19. Saatchi, S.; Halligan, K.; Despain, D.G.; Crabtree, R.L. Estimation of forest fuel load from radar remote sensing. IEEE Trans. Geosci. Remote Sens. 2007, 45, 1726-1740.

20. Tsui, O.W.; Coops, N.C.; Wulder, M.A.; Marshall, P.L.; McCardle, A. Using multi-frequency radar and discrete-return LiDAR measurements to estimate above-ground biomass and biomass components in a coastal temperate forest. ISPRS J. Photogramm. Remote Sens. 2012, 69, 121-133.

21. Tian, X.; Su, Z.; Chen, E.; Li, Z.; van der Tol, C.; Guo, J.; He, Q. Estimation of forest above-ground biomass using multi-parameter remote sensing data over a cold and arid area. Int. J.Appl. Earth Obs. Geoinf. 2012, 14, 160-168.

22. He, Q.; Xu, H.; Zhang, Y. Estimation of Forest Biophysical Parameters Using Small-Footprint LiDAR with low Density in a Coniferous Forest. In Proceedings of International Symposium on Lidar and Radar Mapping 2011: Technologies and Applications, Nanjing, China, 26-29 May 2011; Volume 8286.

23. Zhou, Y.; Zhu, Q.; Chen, J.M.; Wang, Y.Q.; Liu, J.; Sun, R.; Tang, S. Observation and simulation of net primary productivity in Qilian Mountain, western China. J. Environ. Manag. 2007, 85, 574-584.

24. Wang, J.Y.; Ju, K.J.; Fu, H.E.; Chang, X.X.; He, H.Y. Study on biomass of water conservation forest on North Slope of Qilian Mountains. J. Fujian Coll. For. 1998, 18, 319-323.

25. Chan, N.; Takeda, S.; Suzuki, R.; Yamamoto, S. Establishment of allometric models and estimation of biomass recovery of swidden cultivation fallows in mixed deciduous forests of the Bago Mountains, Myanmar. For. Ecol. Manag. 2013, 304, 427-436. 
26. Kenzo, T.; Furutani, R.; Hattori, D.; Kendawang, J.J.; Tanaka, S.; Sakurai, K.; Ninomiya, I. Allometric equations for accurate estimation of above-ground biomass in logged-over tropical rainforests in Sarawak, Malaysia. J. For. Res. 2009, 14, 365-372.

27. Kenzo, T.; Ichie, T.; Hattori, D.; Itioka, T.; Handa, C.; Ohkubo, T.; Kendawang, J.J.; Nakamura, M.; Sakaguchi, M.; Takahashi, N.; et al. Development of allometric relationships for accurate estimation of above- and below-ground biomass in tropical secondary forests in Sarawak, Malaysia. J. Trop. Ecol. 2009, 25, 371-386.

28. Axelsson, P.E. Processing of laser scanner data-Algorithms and applications. ISPRS J. Photogramm. Remote Sens. 1999, 54, 138-147.

29. Kraus, K.; Pfeifer, N. Determination of terrain models in wooded areas with airborne laser scanner data. ISPRS J. Photogramm. Remote Sens. 1998, 53, 193-203.

30. Means, J.E.; Acker, S.A.; Fitt, B.J.; Renslow, M.; Emerson, L.; Hendrix, C.J. Predicting forest stand characteristics with airborne scanning Lidar. Photogramm. Eng. Remote Sens. 2000, 66, 1367-1371.

31. Treitz, P.; Lim, K.; Woods, M.; Pitt, D.; Nesbitt, D.; Etheridge, D. LiDAR sampling density for forest resource inventories in Ontario, Canada. Remote Sens. 2012, 4, 830-848.

32. Naesset, E. Practical large-scale forest stand inventory using a small-footprint airborne scanning laser. Scand. J. For. Res. 2004, 19, 164-179.

33. Cao, C.; Bao, Y.; Xu, M.; Chen, W.; Zhang, H.; He, Q.; Li, Z.; Guo, H.; Li, J.; Li, X.; et al. Retrieval of forest canopy attributes based on a geometric-optical model using airborne LiDAR and optical remote-sensing data. Int. J. Remote Sens. 2012, 33, 692-709.

34. Li, Y.; Andersen, H.-E.; McGaughey, R. A Comparison of statistical methods for estimating forest biomass from light detection and ranging data. West. J. Appl. For. 2008, 23, 223-231.

35. Vincent, G.; Sabatier, D.; Blanc, L.; Chave, J.; Weissenbacher, E.; Pelissier, R.; Fonty, E.; Molino, J.F.; Couteron, P. Accuracy of small footprint airborne LiDAR in its predictions of tropical moist forest stand structure. Remote Sens. Environ. 2012, 125, 23-33.

36. O'Brien, R.M. A caution regarding rules of thumb for variance inflation factors. Qual. Quant. 2007, 41, 673-690.

37. Popescu, S.C.; Wynne, R.H.; Nelson, R.F. Measuring individual tree crown diameter with Lidar and assessing its influence on estimating forest volume and biomass. Can. J. Remote Sens. 2003, 29, 564-577.

38. Lim, K.; Treitz, P.; Baldwin, K.; Morrison, I.; Green, J. Lidar remote sensing of biophysical properties of tolerant northern hardwood forests. Can. J. Remote Sens. 2003, 29, 658-678.

(C) 2013 by the authors; licensee MDPI, Basel, Switzerland. This article is an open access article distributed under the terms and conditions of the Creative Commons Attribution license (http://creativecommons.org/licenses/by/3.0/). 